\title{
The learner's self-regulation and academic success
}

\section{La autorregulación del aprendiz y su éxito académico}

\author{
TEJERO-MENA, Paulo†*, CUEVAS-SOSA, Jorge and VERA-CHI, Lucely \\ Universidad Tecnológica Regional del Sur. Directorate of Accounting, Mexico.
}

ID $1^{\text {st }}$ Author: Paulo, Tejero-Mena / ORC ID: 0000-0002-8368-5732, CVU CONACYT ID: 297306

ID $1^{\text {st }}$ Co-author: Jorge, Cuevas-Sosa / ORC ID: 0000-0003-0685-1116, CVU CONACYT ID: 298582

ID $2^{\text {nd }}$ Co-author: Lucely, Vera-Chi / ORC ID: 0000-0003-2946-8937, CVU CONACYT ID: 272493

DOI: $10.35429 / E J R P .2020 .10 .6 .1 .6$

Received January 10, 2020; Accepted June 30, 2020

\begin{abstract}
This study was motivated by the low levels of academic achievement obtained by the University students, the objective was to explain the difference between those who are successful and those who are not. The theory of selfregulation of learning was used, so to identify them, a descriptive, non-experimental, cross-sectional, correlational study was carried out, with a convenience sample. The data were obtained through a survey, which reflects self-regulated learning, applied to 268 students, and was analyzed using the SPSS 18 statistic. The result was that, of the two roles of self-regulated learning, the one that has a greater relationship with outstanding academic performance was that of learning strategies in the components: metacognitive self-regulation and regulation of effort. Regarding the role of motivation, only the anxiety component was related to this performance, in the opposite direction: the higher the anxiety, the lower the academic performance. It is recommended to implement an institutional program to reinforce learning strategies, with special emphasis on metacognitive self-regulation and effort regulation. In the case of anxiety, it is recommended to deepen the study of the causes that originate it, to reduce its incidence.
\end{abstract}

Learning, self-regulated learning and effective learning

\begin{abstract}
Resumen
Este estudio fue motivado por los bajos niveles de aprovechamiento académico obtenido por los estudiantes de la Universidad, el objetivo fue explicar la diferencia entre aquellos que son exitosos y los que no. Se utilizó la teoría de la autorregulación del aprendizaje, por lo que para identificarlos se efectuó un estudio descriptivo no experimental, transversal, de tipo correlacional, con una muestra por conveniencia. Los datos fueron obtenidos a través de una encuesta, que refleja el aprendizaje autorregulado, aplicada a 268 alumnos y fueron analizadas mediante el estadístico SPSS 18. El resultado fue que, de los dos roles del aprendizaje autorregulado, el que tiene una mayor relación con el rendimiento académico sobresaliente fue el de las estrategias de aprendizaje en los componentes: autorregulación metacognitiva y regulación del esfuerzo. En cuanto al rol de la motivación, únicamente el componente ansiedad presentó relación con este rendimiento, en sentido inverso: a mayor ansiedad menor rendimiento académico. Se recomienda implementar un programa institucional de reforzamiento de las estrategias de aprendizaje, dando especial énfasis en las de autorregulación metacognitiva y de regulación del esfuerzo. En el caso de la ansiedad, se recomienda profundizar en el estudio de las causas que la originan, para reducir su incidencia.
\end{abstract}

Aprendizaje, Aprendizaje autorregulado y Aprendizaje eficaz

Citation: TEJERO-MENA, Paulo, CUEVAS-SOSA, Jorge and VERA-CHI, Lucely. The learner's self-regulation and academic success. ECORFAN Journal-Republic of Peru. 2020. 6-10:1-6.

\footnotetext{
* Author Correspondence (Email: paulotejero@gmail.com)

$\dagger$ Researcher contributing as the first author.
} 


\section{Introduction}

Over the years, a constant deterioration in the academic performance of the students of this institution has been observed, regardless of the academic program to which they are enrolled. It is important to mention that since the gradual implementation of the competency-based learning model, this deterioration has been more evident, worsening the gap between outstanding students and those who are not. Which leads to the following statements, what are the factors that characterize the profile of a student with self-regulated learning? Are these factors common to all academically outstanding students?

The fact of verifying if the presence of the factors that characterize a self-regulated learning profile results in academically outstanding students, will allow the educational authorities of the Southern Regional Technological University to have information for making decisions that have the purpose of adapting its educational strategies in such a way that they lead it to achieve its mission as an institution and to consolidate its presence in the region.

It will also allow students to develop their capacities through the approach of strategies in order to promote self-regulated learning without this meaning adding special courses or workshops. The strategies must be within the framework of the subject that the student is studying; which means that teachers must also exercise their role within the context of competencies.

All this will have a direct impact on generating competent professionals to achieve their better insertion into economic and social life, which will result in a comprehensive improvement in their communities of origin and in the region in general.

In the Introduction section, we describe the problem that we want to solve, its importance for our institution, its main characteristics and the hypothesis that we want to demonstrate by characterizing the chosen theory. In the Development we explain the type of study carried out, the instrument used. The population we work with, as well as the main results obtained.
Finally, we point out the conclusions we reached regarding whether the presence of the different components of Self-regulated Learning affect the better academic achievement of university students, as well as the suggestions we make to improve our educational performance based on in the same.

\section{Development}

The research was non-experimental, there was no deliberate manipulation of variables, within the non-experimental studies the descriptive and correlational transectional design was chosen, characterized by the collection of information in a single time and moment.

The MSLQ (Motivated Strategies Learning Questionnaire) instrument was applied, an instrument that has a Likert-type response scale format and is organized into two sections.

One of these specifically measures the motivation that is put into play during learning, made up of 31 items; and another, made up of 50 items, assesses the learning strategies. In its totality it is made up of 81 items distributed in 15 scales (Cognition: Essay, Elaboration, Organization, Critical thinking, Metacognition; Motivation and Affectivity: Intrinsic goals, extrinsic goals, Task value, Control over the beliefs of the learning itself, Self-efficacy , Anxiety Test; Behavior: Regulation of effort, Search for help, Environment and study time; Context: Peer learning, Environment and study time; which for its application it was necessary to find in its version in Spanish and complete, the which has been validated in multiple previous studies.

The population was made up of the total number of students in the third semester who are studying one of the careers taught at the Universidad Tecnológica Regional del Sur in its five academic programs, from which 268 valid surveys were applied (table 1).

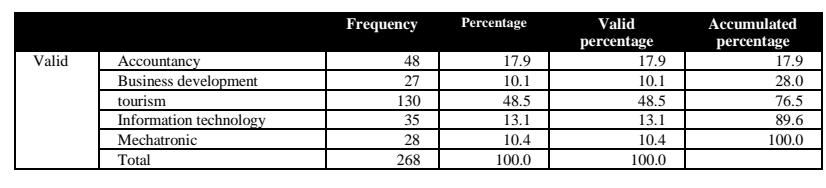

Table 1 Students by career

Source: Own elaboration 
The applied surveys yielded demographic data indicating that the average age and grade is 19 and 8.95 respectively. $62 \%$ are men -162- and $38 \%$ women -101-. The average of studies achieved by both the father and the mother is of the first grade of secondary school and $80 \%$ of the families have incomes of less than five thousand pesos.

The instrument was self-applied by students of all academic programs within the university facilities, either in classrooms or in auditoriums with the authorization of the career directors and with the supervision of the researchers.

The analysis of the data collected in the application of the instrument was carried out with the help of the PASW Statistics 18 program.

\section{Results}

Next, the results of the investigation are presented, by means of tables that indicate the statistical data obtained from the application of the instrument according to the established objectives.

Regarding objective 1, Determine the characteristics of the self-regulated learning profile present in the students of the Universidad Tecnológica Regional del Sur, tables 2, 3, 4 and 5 show the average results according to the sections, components, strategies and scales established in the MSLQ.

\begin{tabular}{|l|c|r|r|r|}
\hline \multicolumn{2}{|c}{$\begin{array}{c}\text { Value } \\
\text { components }\end{array}$} & \multicolumn{1}{c}{$\begin{array}{c}\text { Intrinsic } \\
\text { targeting } \\
\text { goals }\end{array}$} & \multicolumn{1}{c|}{$\begin{array}{c}\text { Extrinsic } \\
\text { orientation } \\
\text { goals }\end{array}$} & Task Value \\
\hline \multirow{2}{*}{$\mathrm{N}$} & Valid & 268 & 268 & 268 \\
\cline { 2 - 5 } & Lost & 0 & 0 & 0 \\
\hline Mean & 3.9935 & 4.3741 & 4.3016 \\
\hline Mode & 3.75 & 5.00 & 4.67 \\
\hline \multicolumn{2}{|l|}{ Dev. typ. } & .55520 & .63508 & .54139 \\
\hline
\end{tabular}

Table 2Descriptive statistics of Motivation Source: Own elaboration

As can be seen in Table 2, on average the university students present high levels of motivation (value 4), in the value components the extrinsic orientation goals being the ones with the highest presence, followed by the value of the task.

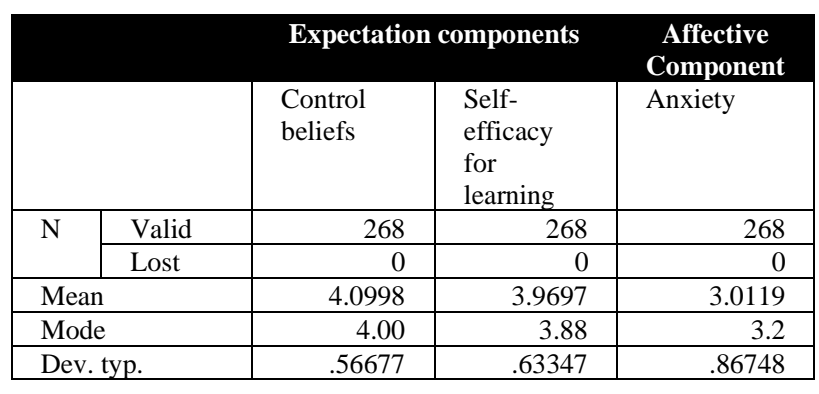

Table 3 Descriptive statistics of Motivation Source: Own elaboration

Table 3 shows that, on average, university students also present high levels of motivation (value 4) in the expectation's components -with a greater presence of the control belief-. The present levels of the affective component anxiety are important since this usually occurs among students (value 3 ).

\begin{tabular}{|c|c|c|c|c|c|c|}
\hline \multirow[t]{2}{*}{$N$} & 268 & 268 & 268 & 268 & 268 & 268 \\
\hline & 0 & 0 & 0 & 0 & 0 & 0 \\
\hline \multicolumn{2}{|c|}{ Mean } & 3.7453 & 3.3744 & 3.5317 & 3.4201 & 3.5628 \\
\hline \multirow{2}{*}{\multicolumn{2}{|c|}{ Mode }} & 4.00 & 3.33 & 3.75 & $3.40^{\mathrm{a}}$ & 3.92 \\
\hline & & .80304 & .77208 & .74100 & .75672 & .60001 \\
\hline
\end{tabular}

Table 4 Descriptive Statistics of Learning Strategies Source: Own elaboration

\begin{tabular}{|c|c|c|c|c|c|}
\hline \multicolumn{2}{|c|}{$\begin{array}{c}\text { Resource } \\
\text { management } \\
\text { strategies }\end{array}$} & $\begin{array}{c}\text { Time and } \\
\text { environment } \\
\text { management }\end{array}$ & $\begin{array}{l}\text { Regulation of } \\
\text { effort }\end{array}$ & Peer learning & Help search \\
\hline \multirow[t]{2}{*}{$\mathrm{N}$} & Valid & 268 & 268 & 268 & 268 \\
\hline & Lost & 0 & 0 & 0 & 0 \\
\hline \multicolumn{2}{|c|}{ Mean } & 3.4991 & 3.7239 & 3.3035 & 3.4991 \\
\hline \multicolumn{2}{|c|}{ Mode } & 3.50 & 3.75 & 3.33 & 3.50 \\
\hline \multicolumn{2}{|c|}{ Dev. typ. } & .57471 & .71910 & .83809 & .57471 \\
\hline
\end{tabular}

Table 5 Descriptive statistics of Learning Strategies Source: Own elaboration

Regarding the section on learning strategies (tables 4 and 5), on average university students usually use them (3), repetition being the most used in terms of cognitive and metacognitive strategies, followed by selfregulation. Regulation of effort is the most widely used strategy in terms of resource management.

From the results obtained in the previous tables, it can be pointed out that university students have higher levels of motivation since this is almost always presented in comparison with those of learning strategies which are usually presented.

Objective 2 of the research is to determine if there is a relationship between the self-regulated learning profiles present at the University and the outstanding academic performance of its students. 
To do this, as indicated in the methodology section, with the total number of students, three groups were created, students with outstanding performance, average and nonoutstanding, based on their general averages. Of these groups, only the first and last were selected to contrast the profiles present in each group and subsequently determine if there is a relationship between the degree of their presence and the performance obtained.

In the first instance, we analyze motivation in its value component (Table 6). The most frequent type of motivation in the case of students considered outstanding is the value of the task, while in non-outstanding students they are extrinsic orientation goals.

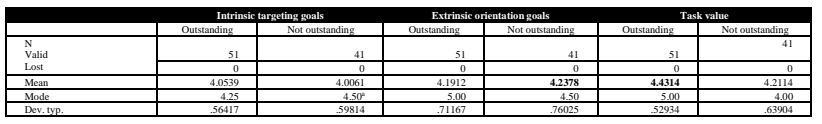

Table 6 Motivation. Value component. Outstanding / Not Outstanding Comparison

Source: Own elaboration

In Tablet 7 it can be observed that the expectation component with the greatest presence for both outstanding and nonoutstanding students is the belief of control.

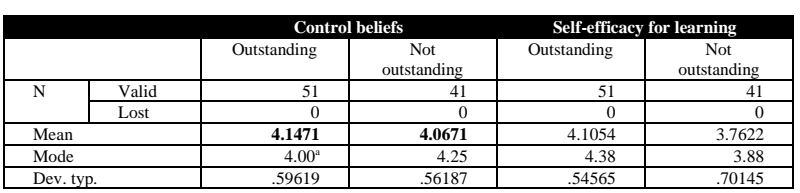

Table 7 Motivation. Expectations component. Outstanding / Not Outstanding Comparison Source: Own elaboration

Regarding the affective component, anxiety, this is present more frequently among non-outstanding students (Table 8).

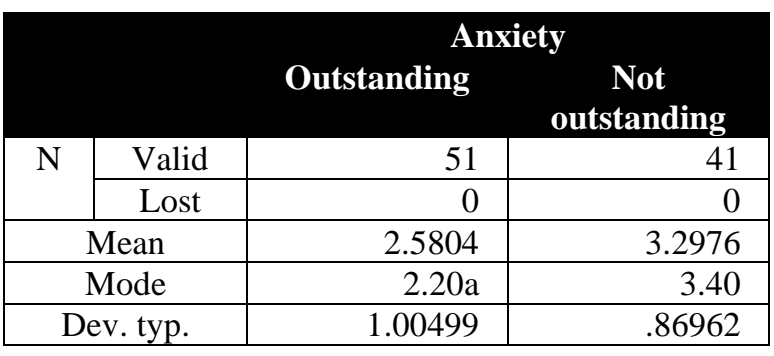

Table 8 Motivation. Affective component. Outstanding / Not Outstanding Comparison Source: Own elaboration

With regard to learning strategies, as we can see in Table 9, repetition is the cognitive strategy most used by both outstanding and nonoutstanding students.

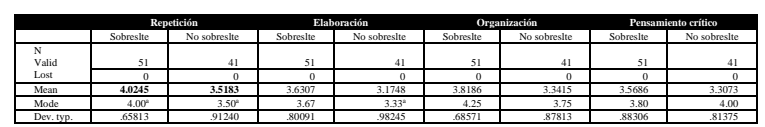

Table 9 Learning strategies. Cognitive strategies. Outstanding / Not Outstanding Comparison Source: Own elaboration

As for metacognitive self-regulation strategies (Table 10), these, in a marked way, have a greater presence in outstanding students.

\begin{tabular}{|c|c|c|c|}
\hline & \multicolumn{2}{|c|}{ Metacognitive self-regulation } \\
\hline & & Outstanding & $\begin{array}{c}\text { Not } \\
\text { outstanding }\end{array}$ \\
\hline \multirow[t]{2}{*}{$\mathrm{N}$} & Valid & 51 & 41 \\
\hline & Lost & 0 & 0 \\
\hline \multicolumn{2}{|c|}{ Mean } & 3.8889 & 3.3028 \\
\hline \multicolumn{2}{|c|}{ Mode } & 4.58 & $2.58^{\mathrm{a}}$ \\
\hline \multicolumn{2}{|c|}{ Dev. typ. } & .59504 & .68307 \\
\hline
\end{tabular}

Table 10 Learning strategies. Metacognitive strategies. Outstanding / Not Outstanding Comparison Source: Own elaboration

Finally, the regulation of effort in outstanding students and the search for help and time management in equal parts for nonoutstanding students, were the resource management strategies that had the greatest presence (Table 11).

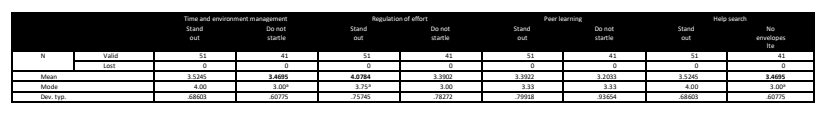

Table 11 Learning strategies. Resource management strategies. Outstanding / Not Outstanding Comparison Source: Own elaboration

Given the results obtained in the contrast of the profiles manifested between the two groups, in which a greater presence of the positive components and strategies is generally observed in students with outstanding performance and of the negative component anxiety- in non-outstanding students, the correlations were determined to establish which of them are effectively related to the presence of better academic performance. The results are shown below in tables 12, 13 and 14 .

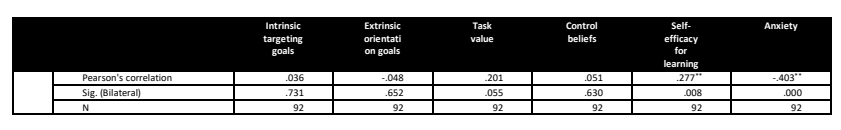

Table 12 Correlations. Motivation / Overall Average Source: Own elaboration 
Analyzing the results of the motivation section present in the university students (Table 12), we observe that none of the value components -intrinsic or extrinsic goals, task value- is related to outstanding performance. For its part of the expectation's components -beliefs of value and self-efficacy for learning-only the latter has a positive correlation although this is low $(0.2$ to 0.39$)$. Where there is a moderate negative correlation ( 0.40 to 0.69$)$ is in the affective component, anxiety. Both the low and moderate correlation were presented with a significance level lower than 0.01 .

Where we find a greater correlation between the self-regulated learning profile and outstanding performance is in the learning strategies section, since in this section we observe from a low correlation in the cognitive strategies of repetition, organization and elaboration, to a moderate one in the strategy of metacognitive self-regulation and in the resource management strategy, effort regulation (tables 13 and 14).

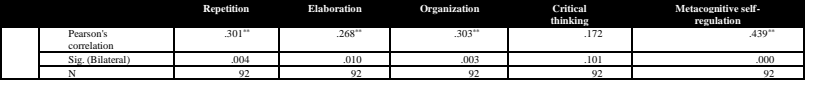

Table 13 Correlations. Learning strategies / General average

Source: Own elaboration

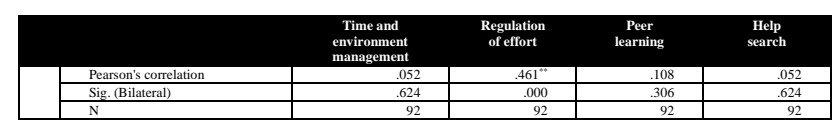

Table 14 Correlations. Learning strategies / General average

Source: Own elaboration

\section{Acknowledgments}

Acknowledgments We are grateful for the support of our institution, which in order to improve the teaching-learning processes for the fulfillment of its mission, allocated time and resources to carry out this research.

\section{Conclusions}

The presence of factors that characterize a selfregulated learning profile results in students of outstanding academic performance. Hence the importance of continuing to carry out studies on this topic, even using different theories to obtain more conclusive evidence, as well as determining relationships between the motivational components and learning strategies themselves to determine the effect they have on each other. If we want to fulfill our educational mission, to develop talented young people who reach their full potential, we must have better institutional tools that contribute to it.

\section{References}

Castellanos, S. y otros. (2011). Cuestionario de Evaluación del Procesamiento Estratégico de la Información para Universitarios. Revista Electrónica de Metodología Aplicada. Vol. 16 No. 2, Pp 15-28.

Cázares, A. (2009). El papel de la motivación intrínseca, los estilos de aprendizaje y estrategias metacognitivas en la búsqueda efectiva de información online. Revista de Medios y Educación. Núm. 35, pp. 73-85. Recuperado el día 10 de julio de 2017 en http://acdc.sav.us.es/ojs/index.php/pixelbit/artic le/viewFile/660/557

Daura, Florencia (2010). DOCENTES. El aprendizaje autorregulado y su orientación por parte del docente universitario. Congreso Iberoamericano de Educación Metas 2021. Recuperado en https://www.researchgate.net/profile/Florencia_ Daura3/publication/228395668_El_aprendizaje _autorregulado_y_su_orientacion_por_parte_de 1_docente_universitario/links/54fdf98f0cf2672e 223e9cb2.pdf.

Delors, J. (1996). La Educación Encierra un Tesoro. Compendio de la UNESCO.

García, J. (2011). Modelo Educativo Basado en Competencias: Importancia y necesidad. Revista Electrónica Actualidades Investigativas en Educación. Vol. 11 No. 3. Pp. 1-24.

Hernández, L. (2015). Autoeficacia Académica y Estrés en estudiantes de Educación Superior Tecnológica. 
Lamas, Héctor (2008). Aprendizaje autorregulado, motivación y rendimiento académico. Liberabit. Recuperado en http://www.scielo.org.pe/pdf/liber/v14n14/a03v 14n14.pdf.

Leal, M. y Martín, M. (2009). Cuestionario de Estrategias y Motivación para el Aprendizaje (MSLQ) por alumnos del ITESM.

Pintrich, P. R. and De Groot, E. V. (1990). Motivational and self-regulated learning components of classroom academic performance. Journal of Educational Psychology 82(1).

Pintrich, P. (1998). El papel de la motivación en el aprendizaje académico autorregulado. En S. Castañeda (coord.). Evaluación y fomento del desarrollo intelectual en la enseñanza de ciencias, artes y técnicas. Perspectiva internacional en el umbral del siglo XXI (pp. 229-262). México: Miguel Ángel Porrúa.

Pintrich, P. (2000). The role of goal orientation in self-regulated learning. In M. Boekaerts, P. Pintrich \& M. Zeidner (eds.). Handbook of SelfRegulation (pp. 451-502). San Diego: Academic Press.

Torrano, Fermín, González, María (2004). El aprendizaje autorregulado presente y futuro de la investigación. Revista Electrónica de Investigación Psicoeducativa. Recuperado en $\mathrm{http}: / / \mathrm{www}$.investigacion-

psicopedagogica.org/revista/articulos/3/espanno 1/Art_3_27.pdf.

Pintrich, P. R. (1998). "El papel de la motivación en el aprendizaje académico autorregulado". En: CASTAÑEDA, S. (Coord.) Evaluación y fomento del desarrollo intelectual en la enseñanza de ciencias, artes y técnicas. Perspectiva internacional en el umbral del siglo XXI. (1era Edición, 229-262) México: Miguel Ángel Porrua.

Pintrich, P. R. (2000). "The role of goal orientation in self-regulated learning". En: BOEKAERTS, M., PINTRICH, PAUL R. \& ZEIDNER, M. (Editors). Handbook of Self Regulation. (1fst. rd. pp. 451-502). San Diego: Academic Press.
Pintrich, P. R. (2002). "The Role of Metacognitive Knowledge in Learning, Teaching, and Assessing". Theory into Practice, Vol. 41, (4), 219-225. Recuperado el 27 de noviembre de 2009, de la base de datos EBSCO.

Pintrich, P. R. (2004). "A Conceptual Framework for Assessing Motivation and SelfRegulated Learning in College Students". [versión electrónica] EducationalPsychology Review, 16 (4): 385-407.

Sepulveda S. M. (2013). Diferencias entre estrategias de aprendizaje y motivación, en grupos progresivos y no progresivos, (Trabajo fin de Master). Recuperado de http://cdigital.dgb.uanl.mx/te/1080256658.

Schunk, D. H. (2005). Self-Regulated Learning: The Educational Legacy of Paul R. Pintrich. Educational Psychologist, 40(2), 85-94. Recuperado el 29 de junio de 2017 en Recuperado de http://dx.doi.org/10.1207/s15326985ep4002_3

Zoraida, J. (1997). La modernización educativa (1988-1994). Journal Article. Vol. 46, No. 4. Homenaje a don Edmundo O'Gorman (Apr. Jun., 1997), pp. 927-952 Publicado por El Colegio de Mexico y Consultado el 20 de junio en Stable URL: http://www.jstor.org/stable/25139099

Zimmerman, B. J. (2000). Attaining self regulation: a social cognitive perspective. In M. Boekaerts, P. Pintrich \& M. Zeidner (eds.). Handbook of Self-Regulation (pp. 13-38). San Diego: Academic Press. www.instagram.com 